\section{IMPLEMENTASI HUKUM DALAM KONTRAK BISNIS INTERNASIONAL ${ }^{1}$}

Oleh : Lileys Glorydei Gratia Gijoh ${ }^{2}$

Jeany Anita Kermite ${ }^{3}$

Jeannie C. Rotinsulu ${ }^{4}$

\section{ABSTRAK}

Tujuan dilakukannya penelitian ini adalah untuk mengetahui bagaimana Pengaturan Hukum Dalam Kontrak Bisnis Internasional dan bagaimana Implementasi Hukum Penyelesaian Sengketa Dalam Kontrak Bisnis Internasional. Dengan menggunakan metode penelitian yuridis normatif, disimpulkan: 1. Pengaturan Hukum Dalam Kontrak Bisnis Internasional dapat dijumpai pada kaidah dan prinsip-prinsip hukum kontrak internasional yang mengatur mengenai ketentuan-ketentuan transaksi bisnis internasional. Adapun ketentuan dalam konvensi internasional tersebut mengenai Contracts for the internasional Sale of Goods (CISG) dan the UNIDROIT Principle of International Contracts Tahun 1994. Prinsipprinsip UNIDROIT merupakan sumber hukum kontrak internasional yang dibuat sebagai upaya menciptakan harmonisasi hukum dan aturan-aturan dalam perdagangan internasional. Prinsip-prinsip hukum kontrak tersebut diantaranya adalah; Prinsip kebebasan berkontrak, Prinsip pengakuan hukum terhadap kebiasaan bisnis, Prinsip itikad baik (good faith) dan transaksi jujur (fair dealing), Prinsip force majeure dan Retroactive effect of Avoidance (tidak berlaku surut). 2. Mengenai forum atau bentuk penyelesaian sengketa yang tersedia, tampak masing-masing memiliki kekuatan dan kelemahannya. Baik itu APS atau pengadilan, masing-masing memiliki cirinya. Menurut bentuknya, pilihan hukum dapat berupa pilihan yang secara tegas dinyatakan oleh para pihak dalam suatu klausul kontrak yang di dalamnya ditegaskan suatu sistem hukum tertentu yang mereka pilih. Pilihan hukum dapat dilakukan secara diam-diam atau tersirat. Pilihan hukum juga dapat diserahkan kepada pengadilan berdasarkan kesepakatan dari para pihak, yang biasanya ditempuh bilamana para pihak gagal

\footnotetext{
${ }^{1}$ Artike Skripsi

2 Mahasiswa pad Fakultas Hukum Unsrat, NIM. 16071101048

${ }^{3}$ Fakultas Hukum Unsrat, Magister Ilmu Hukum

${ }^{4}$ Fakultas Hukum Unsrat, Doktor IImu Hukum
}

atau kesulitan dalam mencapai kesepakatan mengenai hukum yang akan dipilih.

Kata kunci: Implementasi Hukum, Kegiatan Transaksi, Bisnis Internasional

\section{PENDAHULUAN}

\section{A. Latar Belakang Masalah}

Dalam bisnis internasional, kontrak memiliki peran yang penting, peran ini tampak dari semakin meningkatnya transaksi dagang yang sudah lintas batas. Transaksi-transaksi dagang demikian biasanya dituangkan dalam dokumendokumen kontrak. Dengan semakin meningkatnya bentuk-bentuk transaksi dagang telah membawa konsekuensi lain, dimana dengan semakin berkembangnya transaksi dagang, semakin berkembang pula bentukbentuk kontrak internasional. Karena kontrak tidak lain adalah kesepakatan atau perjanjian yang melahirkan hukum, maka hukum yang mengatur bidang ini pun konsekuensinya adalah lahir dan berkembang dari adanya kesepakatan-kesepakatan para pihak.

Profesor Sudargo Gautama (1976) berpendapat bahwa hukum kontrak internasional adalah kontrak nasional yang di dalamnya ada unsur-unsur asing atau unsur luar negeri (foreign element). ${ }^{5}$ Batasan Profesor Sudargo Gautama ini sudah menjadi doktrin. Karena bidang hukum kontrak ini pada hakekatnya adalah hukum nasional, maka untuk bidang hukum ini sifatnya bukan saja hidup dan berkembang sesuai dengan perkembangan dunia bisnis, tetapi juga telah turut campurnya peran pemerintah.

Peran ini terutama memang dibutuhkan karena adanya kepentingan umum yang harus dilindungi. Peran pemerintah juga sangat penting mengingat untuk kontrak-kontrak internasional, perhatian dan kepentingan negara di dalamnya sudah barang tentu sulit dihindari.

Setiap kontrak-kontrak dengan pihak asing akan memperlihatkan berbagai masalah dan berbagai persoalan dalam prakteknya. Untuk itu diperlukan aturan-aturan yang berlaku atas kontrak yang dibuat tersebut. Contohnya dalam kontrak-kontrak yang dibuat antara pihak Indonesia dan pihak asing, sering kali terdapat klausul-klausul tentang hukum yang berlaku

\footnotetext{
5 Sudargo Gautama, Hukum Perdata Internasional
} Indonesia, Binacipta, Jakarta. 1976, hal. 6 
(applicable law) untuk kontrak bersangkutan. Apabila kontrak-kontrak itu dibuatkan konsepnya oleh seorang penasihat hukum dari perusahaan-perusahaan bersangkutan, maka tidak terkecuali selalu akan terdapat pasal yang mengatur hukum yang harus berlaku.

Berdasarkan uraian diatas penulis tertarik untuk menulis karya tulis ilmiah dalam bentuk skripsi ini dengan judul : " Implementasi Hukum Dalam Kontrak Bisnis Internasional ."

\section{B. Perumusan Masalah}

1. Bagaimanakah Pengaturan Hukum Dalam Kontrak Bisnis Internasional ?

2. Bagaimanakah Implementasi Hukum Penyelesaian Sengketa Dalam Kontrak Bisnis Internasional ?

\section{Metode Penelitian}

Secara umum, ruang lingkup penelitian ini merupakan disiplin ilmu hukum, yakni Hukum Bisnis dan Hukum Dagang Internasional khususnya berkaitan dengan implementasi hukum kegiatan bisnis internasional internasional. maka penelitian ini merupakan bagian dari penelitian hukum yakni dengan cara meneliti bahan pustaka yang dinamakan penelitian hukum kepustakaan. ${ }^{6}$ Sedangkan metode pendekatan yang digunakan dalam penelitian ini adalah yuridis normatif, yaitu penelitian yang difokuskan untuk mengkaji penerapan kaidah-kaidah atau norma-norma dalam hukum normatif. ${ }^{7}$

\section{PEMBAHASAN}

\section{A. Pengaturan Hukum Dalam Kontrak Bisnis Internasional}

Bisnis Internasional adalah bisnis dimana kegiatan bisnis terdiri dari transaksi bisnis antara pihak yang berasal dari lebih satu negara. Disebut juga pemasaran internasional sebagai transaksi bisnis yang dilakukan oleh perusahaan dalam satu negara dengan perusahaan lain atau individu di negara lain atas dasar kesepakatan bersama. Pihak yang dimaksud dapat berupa antar individu, antar individu dengan pemerintah suatu negara maupun pemerintah suatu negara dengan

\footnotetext{
6 Soerjono Soekanto dan Sri Mamudji, Penelitian Hukum Normatif, Rajawali, Jakarta, 1985, hal. 14.

7 Johnny Ibrahim, Teori dan Metodologi Penelitian Hukum Normatif, Bayu Media, Malang, 2008, hlm.306. 92
}

pemerintahan negara lain.

Pengaturan hukum transaksi bisnis internasional, terkategori berada dalam ranah hukum privat, sehingga terhadapnya diberikan kebebasan kepada para pihak untuk menentukan isi perjanjian yang menjadi prestasi dalam sebuah perikatan. Meskipun demikian, transaksi bisnis yang dilakukan oleh dua subjek hukum yang berlainan warganegara tersebut harus tetap megindahkan hukum internasional mengenai transaksi bisnis yang mereka lakukan, selain harus memperhatikan kaidah hukum nasional masing-masing negara.

Menurut Huala Adolf ${ }^{8}$, kontrak internasional adalah suatu kontrak yang didalamnya ada atau terdapat unsur asing (Foreign element). Unsur asing yang dimaksud diantaranya adalah adanya subjek hukum yang berbeda kewarganegaraan.

Transaksi bisnis internasional pada umumnya didasarkan pada kontrak yang telah disepakati oleh para pihak. Dengan adanya kontrak yang mengikat tersebut melahirkan keyakinan para pihak terhadap ekspektasi yang akan didapatkannya dari pelaksanaan kontrak tersebut. Dan untuk harapan tersebut para pihak bersedia menggunakan sumber daya yang dimilikinya sebagai imbalan harapan yang diinginkan tersebut.

Untuk memastikan harapan para pihak tersebutlah kontrak yang diikat tidak saja sebagai sumber kewajiban moral, tetapi juga kewajiban hukum yang pelaksanaannya wajib ditaati. ${ }^{9}$ Sebagai konsekwensinya, jika terjadi sengketa, maka hakim maupun pihak ketiga tidak boleh mencampuri isi perjanjian yang dibuat oleh para pihak tersebut. ${ }^{10}$

Dalam melakukan kerja sama bisnis atau transaksi bisnis antar negara, para pelaku bisnis memerlukan kontrak bisnis internasional, baik itu dalam skema antara pemerintah dengan pemerintah ( $G$ to $G$ ), antara pemerintah dengan swasta ( $G$ to $B)$, maupun antara swasta dengan swasta ( $B$ to $B$ ). Kesepakatan mengenai ketentuan-ketentuan dalam kerja sama bisnis atau transaksi bisnis internasional antara

\footnotetext{
8 Huala Adolf, 2008, Dasar-dasar Hukum Kontrak Internasional. Bandung. PT. Refika Aditama. HIm. 1

${ }^{9}$ Fred B.G. Tumbuan, " Kekuatan Mengikat Perjanjian dan Batas-Batasnya, Makalah, Jakarta, Juli 1998, hlm.1

10 Ridwan Khairandy, Itikad Baik dalam Kebebasan Berkontrak, Fakultas Hukum, Sekolah Pascasarjana, UI, Jakarta, 2004, hlm. 29
} 
pelaku bisnis yang berasal dari dua negara atau lebih biasanya dituangkan kedalam suatu kontrak bisnis internasional.

Kontrak bisnis internasional merupakan dasar hubungan hukum dan pedoman bersama bagi pelaku bisnis yang berbeda negara dalam melaksanakan kerja sama bisnis atau transaksi bisnis internasional. Oleh karena itu, para pelaku bisnis yang bergiat dalam kerja sama bisnis atau transaksi bisnis internasional harus memahami betul seluk-beluk hukum kontrak bisnis internasional.

Transaksi bisnis internasional merupakan kajian hukum privat, dimana dalam hukum privat, hukum memberikan peluang lebih luas untuk masing-masing pihak membuat, memperjanjikan dan melaksanakan klausul klausul yang mereka buat. Namun tak dapat dipungkuri bahwa untuk dapat menjalankan kegiatan bisnis tersebut, para pihak harus dengan seksama mengerti dan memahami kaidah-kaidah hukum yang ada di Negara para pihak lawan. Hal tersebut sangat akan berpengaruh pada pelaksanaan dariperjanjian tersebut. ${ }^{11}$

Prinsip-prinsip hukum yang diatur dalam transaksi bisnis internasional mengacu pada prinsip-prinsip hukum perjanjian/kontrak internasional yang disepakati oleh para pihak, dan konvensi perdagangan internasional (international trade convention). Prinsip-prinsip hukum bisnis internasional ini dapat dilihat dari keberlakuan/ sumber hukum kontrak internasional, Huala Adolf ${ }^{12}$ dalam bukunya menjelaskan bahwa terdapat 7 (tujuh) bentuk hukum yang dapat menajdi sumber hukum kontrak internaisonal, yakni :

1. Hukum Nasional

2. Dokumen Kontrak

3. Kebiasaan-kebiasaan di bidang perdagangan internasional yang terkait dengan kontrak

4. Prinsip-prinsip hukum umum mengenai kontrak

5. Putusan pengadilan

6. Doktrin

7. Perjanjian internasional mengenai kontrak.

\footnotetext{
11 Wiwin Dwi Ratna, Zulvia Makka, Perlindungan Hukum Transaksi Bisnis Internasional Era Perdagangan Bebas, Jurnal Universitas Borneo Tarakan, hal. 2

12 Huala Adolf, Op-Cit, hal. 61
}

Dari ketujuh sumber hukum tersebut, maka dapat dijelaskan bahwa, meskipun kontrak bisnis internasional merupakan ranah hukum privat, dan menerapkan prinsip hukum kebebasan berkontrak dan prinsip kedaulatan, namun tetap harus mengindahkan beberepa sumber hukum kontrak internasional lainnya.

\section{B. Implementasi Hukum Penyelesaian Sengketa Dalam Kontrak Bisnis Internasional}

Penyelesaian sengketa, baik kepada pengadilan maupun ke arbitrase, kerap kali didasarkan pada suatu perjanjian di antara para pihak. Langkah yang biasa ditempuh adalah dengan membuat suatu perjanjian atau memasukkan suatu klausul penyelesaian sengketa ke dalam kontrak atau perjanjian yang mereka buat, baik ke pengadilan atau ke badan arbitrase. Pada umumnya di samping menyepakati lembaga atau forum yang akan menyelesaikan sengketa para pihak perlu juga menyepakati hukum apa yang akan diterapkan oleh badan peradilan yang baru disepakati para pihak.

Dasar hukum dari forum atau badan penyelesaian sengketa yang akan menangani sengketa adalah kesepakatan para pihak. Kesepakatan tersebut diletakkan, baik pada waktu kontrak ditandatangani atau setelah sengketa timbul. Biasanya pula kelalaian para pihak untuk menentukan forum ini akan berakibat pada kesulitan dalam penyelesaian sengketanya karena dengan adanya kekosongan pilihan forum tersebut akan menjadi alasan yang kuat bagi setiap forum untuk menyatakan dirinya berwenang untuk memeriksa suatu sengketa.

Lazimnya dalam sistem hukum (Common Law) dikenal dengan konsep long arm jurisdiction (kekuasaan yurisdiksi). Dengan konsep ini, pengadilan dapat menyatakan kewenangannya untuk menerima setiap sengketa yang dibawa ke hadapannya meskipun hubungan antara pengadilan dengan sengketa tersebut tipis sekali. Misalnya, badan peradilan di Amerika Serikat dan Inggris kerap kali selalu menerima sengketa yang para pihak serahkan ke hadapannya meskipun hubungan atau keterkaitan sengketa dengan badan peradilan sangatlah kecil.

Di samping forum pengadilan, para pihak 
dapat pula menyerahkan sengketanya kepada cara alternatif penyelesaian sengketa, yang lazim dikenal sebagai ADR (Alternative Dispute Resolution) atau APS (Alternatif Penyelesaian Sengketa). Pengaturan alternatif disini dapat berupa cara alternatif disamping pengadilan. Bisa juga berarti alternatif penyelesaian secara umum, yaitu berbagai alternatif penyelesaian sengketa yang para pihak dapat gunakan, termasuk alternatif penyelesaian melalui pengadilan. Biasanya pula dalam klausul tersebut dimasukkan atau dinyatakan pula hukum yang akan diterapkan oleh badan penyelesaian sengketa.

Dalam praktek perdagangan internasional sering terjadi munculnya kasus-kasus yang mempersoalkan tentang hukum negara mana yang akan dipakai apabila terjadi suatu perselisihan. Jawaban atas persoalan ini adalah terletak pada persetujuan para pihak yang bersangkutan yang termuat dalam kontrak dimana mereka sepakat memuat klausula tentang hokum negara mana yang akan dipakai. ${ }^{13}$

Umumnya sengketa-sengketa dagang kerap didahului oleh penyelesaian dengan negosiasi. Manakala cara penyelesaian ini gagal atau tidak berhasil, barulah ditempuh cara-cara lainnya seperti penyelesaian melalui pengadilan atau arbitrase.

Masalah pilihan hukum yang akan diberlakukan atau diterapkan adalah salah satu masalah yang penting dalam suatu kontrak perdagangan internasional. Istilah-istilah pilihan hukum dalam bahasa lain antara lain adalah: Partij autonomie, autonomie des parties (Perancis), intension of the parties(Inggris) atau (choice of law). Para pihak dalam suatu kontrak bebas untuk melakukan pilihan, mereka dapat memilih sendiri hukum yang harus dipakai untuk kontrak mereka. Para pihak dapat memilih hukum tertentu. ${ }^{14}$

Alternative dispute resolution (ADR) atau alternatif penyelesaian sengketa (APS) merupakan upaya penyelesaian sengketa di luar litigasi (non-litigasi). Dalam ADR/APS terdapat beberapa bentuk penyelesaian

13 Chairul Anwar, Hukum Perdagangan Internasional, Novindo Pustaka Mandiri, Jakarta 1999, halaman 93.

14 Sudargo Gautama, Pengantar Hukum Perdata Internasional Indonesia, Bandung: Penerbit Binacipta, cet. Ke-5, 1987, hlm. 204 sengketa. Bentuk-bentuk ADR/APS menurut Suyud Margono (2000:28-31) adalah: (1) konsultasi; (2) negosiasi; (3) mediasi; (4) konsiliasi; (5) arbitrase; (6) good offices; (7) mini trial; (8) summary jury trial; (9) rent a judge; dan (10) med arb ${ }^{15}$.

Mengenai hukum apa yang akan dipilih dan diberlakukan terhadap kontrak, bergantung sepenuhnya kepada kesepakatan para pihak. Ada berbagai hukum yang dapat para pihak pilih. Hukum tersebut adalah: (1) Hukum nasional suatu negara, khususnya hukum nasional dari salah satu pihak; (2) Hukum kebiasaan; (3) Perjanjian internasional; dan (4) Hukum internasional.

1. Hukum Nasional

Dipilihnya suatu hukum nasional oleh para pihak adalah pilihan yang paling umum dilakukan. Bahkan di negara-negara yang sedang berkembang, pilihan hukum nasional adalah pilihan yang dalam hal tertentu diwajibkan. Sebagai contoh, seorang pengusaha Singapura menandatangani kontrak distribusi produk pertanian dengan seorang pengusaha Indonesia. Pilihan hukum dapat berupa salah satu hukum negara peserta ini yang membawa konsekuensi terhadap kontrak. Pilihan hukum tersebut akan menentukan hukum mana yang akan berlaku untuk menentukan sah tidaknya kontrak dan bagaimana kontrak tersebut harus ditafsirkan.

Sebagai contoh, misalnya, aturan-aturan kontrak atau syarat-syarat untuk sahnya suatu perjanjian di Indonesia yang tercantum dalam Kitab Undang-Undang Hukum Perdata (KUH Perdata) Buku III Bab ke II Bagian ke II Pasal 1320-1337. Dimana dalam Pasal 1320 menyatakan: ${ }^{16}$

Untuk sahnya suatu perjanjian diperlukan empat syarat:
a. sepakat mereka yang mengikatkan dirinya;
b. kecakapan untuk membuat suatu perikatan;
c. suatu hal tertentu;
d. suatu sebab yang halal.

\footnotetext{
15 Ros Angesti Anas Kapindha, Salvatia Dwi M, and Winda Rizky Febrina, "Efektivitas dan Efisiensi Alternative Dispute Resolution (ADR) Sebagai Salah Satu Penyelesaian Sengketa Bisnis Di Indonesia", Privat Law 12, No. 4 (2014), hlm 7.

16 Lihat, Kitab Undang-Undang Hukum Perdata
} 
Perlu pula diperhatikan dalam pilihan hukum nasional ini adalah sistem hukum yang berlaku di negara yang dipilih. Manakala suatu negara menganut sistem ketatanegaraan federal, maka perlu untuk secara jelas menentukan hukum negara bagian mana yang akan dipilih. Cukup banyak negara yang menganut sistem hukum federal ini. Misalnya, Amerika Serikat, Kanada, Australia, Malaysia, dan lain-lain.

2. Hukum Kebiasaan Internasional

Para pihak dapat dan bebas pula untuk memilih hukum kebiasaan sebagai hukum yang akan berlaku terhadap kontrak. Pilihan hukum ini biasanya dipilih untuk suatu objek atau transaksi dalam suatu kontrak. Pilihan ini sengaja dipilih karena memang hukum yang mengatur objek atau suatu transaksi telah terkristalisasi menjadi suatu hukum kebiasaan internasional yang dikenal umum. Hukum kebiasaan internasional sudah diakui kekuatan mengikatnya. Berbagai instrumen hukum kontrak internasional, bahkan hukum nasional Indonesia seperti termuat dalam Pasal 1339 dan $1347 \mathrm{KUH}$ Perdata mengakui eksistensi hukum kebiasaan ini.

Pasal 1339 KUH Perdata menyatakan:

"Suatu perjanjian tidak hanya mengikat untuk hal-hal yang dengan tegas dinyatakan didalamnya. tetapi juga untuk segala sesuatu yang menurut sifat perjanjian, diharuskan oleh kepatutan, kebiasaan atau undang-undang."

Sedangkan Pasal 1347 KUH Perdata menyatakan:

"Hal-hal yang menurut kebiasaan selamanya diperjanjikan, dianggap secara diam-diam dimasukkan dalam perjanjian, meskipun tidak dengan tegas dinyatakan."

3. Perjanjian Internasional

Para pihak dapat pula memilih perjanjian internasional yang mengatur kontrak internasional. Salah satu contoh adalah pilihan dan pemberlakuan The United Nations Convention on Contracts for the International Sale of Goods (CISG) Tahun 1980, yaitu konvensi tentang Jual Beli Internasional. Pilihan hukum perjanjian internasional ini biasanya terbatas pada suatu kondisi, yaitu apakah negara dari para pihak dalam kontrak adalah anggota atau terikat pada konvensi atau perjanjian internasional tersebut.

Di Indonesia, perjanjian internasional diatur dan tunduk pada UU Nomor 24 Tahun 2000 tentang Perjanjian Internasional. Dalam Pasal 1 Ayat (1) undang-undang tersebut. perjanjian internasional didefinisikan sebagai berikut:

"Perjanjian Internasional adalah perjanjian, dalam bentuk dan nama tertentu, yang diatur dalam hukum internasional yang dibuat secara tertulis serta menimbulkan hak dan kewajiban di bidang hukum publik."

Perjanjian internasional dapat berupa perjanjian bilateral yang berlaku antara dua negara. Perjanjian bilateral seperti ini berpengaruh secara langsung atau tidak langsung, yaitu dapat berupa perjanjian di bidang navigasi, perdagangan atau persahabatan. Bentuk perjanjian lainnya adalah perjanjian multilateral yang berlaku bagi lebih dari dua negara, yaitu yang bersifat soft-law atau tidak mengikat, yang berupa Model Law on International Commercial Arbitration dan perjanjian yang bersifat hard-law atau bersifat mengikat, yang dapat berupa pernyataan penundukan secara sukarela terhadap perjanjian internasional

4. Hukum Internasional

Pilihan hukum internasional merupakan sesuatu hal yang agak kontroversial. Namun demikian, pilihan hukum ini telah digunakan sebagai alternatif untuk kontrak-kontrak yang salah satu pihaknya adalah negara. Satu alasan yang banyak ditemui adalah karena pada prinsipnya hukum internasional lebih banyak mengatur hubungan-hubungan yang sifatnya lintas batas di bidang hukum publik, bukan perdata.

Kita dapat melihat contoh kasus yang terjadi antara perusahaan minyak Amerika Serikat Texaco dengan pemerintah Libya, yaitu sengketa Texaco vs Libya (Texaco Overseas Petroleum Co and California Arabic Oil Co vs Libya, 1977). ${ }^{17}$ Dalam sengketa ini terangkat peran hukum internasional sebagai lex causae (dasar hukum). Dalam sengketa ini, Libya menasionalisasi semua aset. harta milik serta hak-hak perusahaan Amerika Serikat dalam kontrak konsesi.

Klausul 28 dalam kontrak konsesi tersebut mengenai hukum yang akan berlaku terhadap kontrak. yang menyatakan sebagai berikut:

\footnotetext{
${ }^{17}$ Huala Adolf , Loc.cit. hal.8
} 
"konsesi harus ditafsirkan dan diatur menurut prinsip-prinsip hukum dari kebiasaan Libya kepada prinsip-prinsip hukum internasional dan dalam ketidakadaan prinsip-prinsip kebiasaan seperti itu kemudian menurut prinsipprinsip hukum umum, termasuk semua prinsip-prinsip seperti itu mungkin telah diterapkan oleh pengadilan internasional “

Dalam pilihan tersebut tampak bahwa hukum Libya-lah yang akan berlaku terhadap kontrak konsesi. Namun. hukum Libya tersebut terbatas daya berlakunya, yaitu sepanjang sesuai atau sama pengaturannya dengan prinsip-prinsip hukum internasional. Dalam menafsirkan atau mengartikan prinsip-prinsip hukum internasional yang dimaksud, memang sangat sulit. Untuk itu dalam penerapan hukum ini, arbitrator tunggal untuk kasus ini yaitu professor Dupuy yang adalah seorang arbitrator berkebangsaan Perancis dengan tetap telah menyatakan bahwa hukum yang akan berlaku terhadap kontrak konsesi tersebut adalah hukum yang dipilih oleh para pihak. Professor Dupuy berpendapat bahwa kontrak yang dibuat antara pemerintah Libya dan perusahaan minyak Amerika Serikat Texaco adalah mengikat sifatnya. Hal ini sesuai dengan prinsip hukum internasional yaitu prinsip pacta sunt servanda. Dengan demikian hukum yang berlaku terhadap kontrak tersebut yaitu prinsip hukum internasional pacta sunt servanda.

5. Kombinasi Beberapa Hukum Tertentu

Dalam praktek dapat terjadi bahwa para pihak dalam suatu kontrak menundukkan ketentuan kontraknya kepada beberapa sistem hukum. Dipilihnya beberapa sistem hukum dalam kontrak dikenal pula dengan metode split proper law. Metode ini telah diakui oleh lembaga internasional seperti misalnya The Institute of International Law (ILA), dimana dalam sidang tahunannya di Athena pada tahun 1979. mengeluarkan suatu resolusi yang berjudul "The Proper Law of the Contract in Agreements Between a State and a Foreign Private Person." Dalam Pasal 2 resolusi. tampak dimungkinkannya pilihan hukum lebih dari satu atau bahkan campuran dari dua sistem atau sumber hukum. Pasal 2 ini secara lengkap berbuny

"para pihak dimungkinkan khususnya dalam memilih hukum yang tepat menyangkut kontrak dari salah satu atau beberapa sistem domestik (dalam negeri) yang sah atau prinsip-prinsip kebiasaan untuk sistem seperti itu, atau prinsipprinsip hukum umum, atau prinsip-prinsip yang diterapkan dalam hubungan ekonomi internasional, atau hukum internasional, atau kombinasi dari sumber-sumber hukum tersebut"

Langkah memilih lebih dari satu sistem hukum untuk mengatur suatu kontrak biasanya ditempuh karena objek dalam kontrak memang tidak dapat atau tidak mungkin diatur secara keseluruhannya oleh satu sistem hukum.

PENUTUP

\section{A. Kesimpulan}

1. Pengaturan Hukum Dalam Kontrak Bisnis Internasional dapat dijumpai pada kaidah dan prinsip-prinsip hukum kontrak internasional yang mengatur mengenai ketentuan-ketentuan transaksi bisnis internasional. Adapun ketentuan dalam konvensi internasional tersebut mengenai Contracts for the internasional Sale of Goods (CISG) dan the UNIDROIT Principle of International Contracts Tahun 1994. Prinsip-prinsip UNIDROIT merupakan sumber hukum kontrak internasional yang dibuat sebagai upaya menciptakan harmonisasi hukum dan aturan-aturan dalam perdagangan internasional. Prinsip-prinsip hukum kontrak tersebut diantaranya adalah; Prinsip kebebasan berkontrak, Prinsip pengakuan hukum terhadap kebiasaan bisnis, Prinsip itikad baik (good faith) dan transaksi jujur (fair dealing), Prinsip force majeure dan Retroactive effect of Avoidance (tidak berlaku surut).

2. Mengenai forum atau bentuk penyelesaian sengketa yang tersedia, tampak masing-masing memiliki kekuatan dan kelemahannya. Baik itu APS atau pengadilan, masing-masing memiliki cirinya. Menurut bentuknya, pilihan hukum dapat berupa pilihan yang secara tegas dinyatakan oleh para pihak dalam suatu klausul kontrak yang di dalamnya ditegaskan suatu sistem hukum tertentu yang mereka pilih. 
Pilihan hukum dapat dilakukan secara diam-diam atau tersirat. Pilihan hukum juga dapat diserahkan kepada pengadilan berdasarkan kesepakatan dari para pihak, yang biasanya ditempuh bilamana para pihak gagal atau kesulitan dalam mencapai kesepakatan mengenai hukum yang akan dipilih.

\section{B. Saran}

1. Diharapkan para pelaku bisnis yang bergiat dalam kerja sama bisnis atau transaksi bisnis internasional harus memahami betul seluk-beluk hukum kontrak bisnis internasional. Namun sebaiknya kontrak bisnis interansional dibuatkan secara tertulis dimana hal ini bertujuan untuk memudahkan pembuktian atas telah terjadinya perbuatan hukum yang didalamnya memberi hak dan kewajiban bagi masingmasing pihak untuk menjalankan prestasinya.

2. Diharapkan dalam proses penyelesaian sebuah sengketa kontrak bisnis internasional harus selalu berakar dari itikad baik para pihak. Dengan adanya itikad baik untuk menyelesaikan sebuah sengketa, sehingga apapun bentuk atau forum penyelesaian sengketa yang akan dipakai pasti akan berjalan dengan lancar dan menemukan keputusan yang memuaskan para pihak yang bersengketa.

\section{DAFTAR PUSTAKA}

Adolf Huala. 2006. Hukum Perdagangan Internasional. PT. RajaGrafindo Persada. Jakarta.

2007. Dasar-dasar Hukum Kontrak Internasional. Refika Aditama. Bandung.

$\begin{array}{ccc} & \text { 2006. Hukum Penyelesaian } \\ & \text { Sengketa Internasional. Sinar } \\ \text { Grafika. Jakarta. } & \\ \text { AK Syahmin 2006. Hukum Kontrak } \\ \text { Internasional. PT. RajaGrafindo } \\ \text { Persada. Jakarta. } \\ \text { Anwar Chairul , Hukum Perdagangan } \\ \text { Internasional, Novindo Pustaka } \\ \text { Mandiri, Jakarta 1999 } \\ \text { Anak Agung Banyu Perwita, Pengantar IImu }\end{array}$

\author{
Hubungan \\ Internasional (Bandung: \\ Rosdakarya, 2011
}

Bayu Seto Hardjowahono, Kontrak-Kontrak Bisnis Transnasional dan UNIDROIT Principles of International Commercial Contracts, Sebuah Pembuka Wawasan, Fakultas Hukum Universitas Katolik Parahyangan, Bandung, 2006

Bryan Welch, "The Cape Town Convention", makalah yang dipresentasikan pada Colloqium on Preliminary Draft of Space Protocol, diselenggarakan oleh UNIDROIT

Budi Rustandi Kartawinata dkk, Bisnis Internasional, PT. Karya Manunggal Lithomas, Bandung, 2014

Cavusgil, S. Tamer., Knight, Gary., Riesenberger, John, Yaprak, Attila. 2008. Conducting Market Research for International Business. New York: Business Expert Press.

Dellisa A. Ridgway dan Mariya A. Thalib, " Globalization and Development : Free Trade, Foreign Aid, Investment and The Rule of Law", California Western International Law Journal, Vol. 33, Spring 2003

Fred B.G. Tumbuan, " Kekuatan Mengikat Perjanjian dan Batas-Batasnya, Makalah, Jakarta, Juli 1998

Fuady Munir. 2003. Hukum Kontrak (Dari Sudut Pandang Hukum Bisnis). PT Citra Aditya Bakti. Bandung.

Arbitrase Nasional

(Alternatif Penyelesaian Sengketa Bisnis), Citra Aditya Bakti,Bandung,sebagaimana dikutip oleh Talib, Idris."Bentuk Putusan Penyelesaian Sengketa Berdasarkan Mediasi." Lex Et Societatis (2013).

Gautama Sudargo. 1976. Kontrak Dagang Internasional Himpunan Ceramah dan Prasaran. Alumni. Bandung. 1987. Pengantar Hukum Perdata Internasional Indonesia.

Binacipta. Bandung.s 2002. Hukum Perdata 
Internasional Indonesia. Alumni. Bandung.

Gabriel Henry, "The UNIDROIT Principles 2010:

An American Perspectives", Makalah disampaikan pada Symposium the 2010 UNIDROIT Principles of International Commercial Contract: University Law Center, Center for transnational Business and the Law

Gunawan Widjaja dan Ahmad Yani, Seri Hukum

Bisnis: Transaksi Bisnis Internasional (Ekspor Impor dan Imbal Beli), Raja Grafindo Persada, Jakarta, 2001

Harahap, M. Y. 2001. Arbitrase. Sinar Grafika. Jakarta.

Ibrahim Johnny, Teori dan Metodologi Penelitian Hukum Normatif, Bayu Media, Malang, 2008

I H Ph Diederiks-Verschoor, An Introduction to Air Law, Edisi Revisi ke 9 oleh Pablo Mendes De Leon, Penerbit Walter Kluwers, The Netherlands, 2012

Jacqueline M. Nolan-Haley, "Alternative Dispute Resolution", West Publishing Company, 1991, sebagaimana dikutip oleh Marwah Diah $M$. "Prinsip dan Bentuk-Bentuk Alternatif Penyelesaian Sengketa Di Luar Pengadilan", Hukum Dan Dinamika Masyarakat (2016)

Khairandy Ridwan, Itikad Baik dalam Kebebasan Berkontrak, Fakultas Hukum, Sekolah Pascasarjana, UI, Jakarta, 2004

Kusumaatmadja Mochtar dan Etty Agoes., Pengantar Hukum Internasional, PT Alumni, Bandung,2003

Muryati, Dewi Tuti, and B. Rini Heryanti. "Pengaturan dan Mekanisme Penyelesaian Sengketa Nonlitigasi di Bidang Perdagangan." Jurnal Dinamika Sosbud 3, No. 1 (2011)

Rakhmawati N. Rosyidah, 2006, Hukum Ekonomi Internasional dalam Era Global, Bayumedia Publishing, Malang

Ros Angesti Anas Kapindha, Salvatia Dwi M, and
Winda Rizky Febrina, "Efektivitas dan Efisiensi Alternative Dispute Resolution (ADR) Sebagai Salah Satu Penyelesaian Sengketa Bisnis Di Indonesia", Privat Law 1 2, No. 4 (2014)

Salim S. Hukum Kontrak, Teori dan Teknik Penyusunan Kontrak, Jakarta: Penerbit Sinar Grafika, cet. Ke-3 2006

Satrio J. 1995. Hukum Perikatan, Perikatan yang Lahir dari Perjanjian. Bandung: PT. Citra Aditya Bakti

Soekanto Soerjono dan Sri Mamudji, Penelitian Hukum Normatif, Rajawali, Jakarta, 1985

Suparman Eman, Pilihan Forum Abitrase dalam Sengketa Komersial untuk Penegakan Keadilan, Tatanusa, Jakarta, 2004

Taryan Soenandar, Prinsip-prinsip UNIDROIT sebagai sumber Hukum Kontrak dan Penyelesaian sengketa bisnis internasional, 2006

Widjaja Gunawan. 2005. Alternatif Penyelesaian Sengketa. PT. RajaGrafindo Persada. Jakarta.

Wiwin Dwi Ratna, Zulvia Makka, Perlindungan Hukum Transaksi Bisnis Internasional Era Perdagangan Bebas, Jurnal Universitas Borneo Tarakan

Winarta Frans Hendra, "Hukum Penyelesaian Sengketa-Arbitrase Nasional Indonesia \& Internasional", (Jakarta:Sinar Grafika Offset:2011),

\section{Sumber lain :}

- Kitab Undang-undang Hukum Perdata (BW).

- Undang-undang Nomor 30 Tahun 1999 tentang Arbitrase dan Alternatif Penyelesaian Sengketa.

- UNCITRAL, Digest of Case Law on the United Nations Convention on Contracts for the International Sales of Goods, 2012 Edition.

- UNIDROIT (the international institute for the unification of private law )

- Convention on the Law Applicable to International Sale of Goods

- Convention for the Unification of Certain Rules for International Carriage by Air, 
Montreal 1999

- United Nations Convention on the Carriage of Goods by Sea, Hamburg, 1978 (Hamburg Rules)

- www. Google.com

- Incoterms, baca Janette Charlery, International Trade Law, M \& E Handbook, UK, 1993.

- http://www.gresnews.com/berita/tips/8836 0-penyelesaian-sengketa-bisnisinternasional/

- https://firmansegaf.blogspot.com/2017/04/ kontrak-bisnis-internasional.html 